Meta

Journal des traducteurs

Translators' Journal

\title{
Multilingual Legal Drafting, Translators' Choices and the Principle of Lesser Evil
}

\section{Karolina Stefaniak}

Volume 58, numéro 1, avril 2013

URI : https://id.erudit.org/iderudit/1023809ar

DOI : https://doi.org/10.7202/1023809ar

Aller au sommaire du numéro

Éditeur(s)

Les Presses de l’Université de Montréal

ISSN

0026-0452 (imprimé)

1492-1421 (numérique)

Découvrir la revue

Citer cet article

Stefaniak, K. (2013). Multilingual Legal Drafting, Translators' Choices and the Principle of Lesser Evil. Meta, 58(1), 58-65. https://doi.org/10.7202/1023809ar
Résumé de l'article

On ne parle guère de la traduction au sein des institutions de l'UE, et si l'on se penche sur le sujet, c'est pour critiquer l'énormité prétendue des coûts qu'elle entraîne, ou, pis encore, sa mauvaise qualité apparente. Il est rare que l'on tente d'appréhender les motifs réels qui conditionnent certains choix du traducteur que l'on se hâte plutôt de juger inappropriés, inattendus ou tout simplement erronés. Par le présent article, nous avons cherché à montrer comment tracer la genèse de tels choix, apparemment incongrus, dans la situation particulière de la traduction par rapport au processus de rédaction juridique dans l'UE et de la position adoptée par les traducteurs vis-à-vis des auteurs des textes traduits, dont l'enjeu, loin d'être purement intellectuel, relève davantage d'un dilemme éthique. Dans bien des cas, ce qu'un observateur externe perçoit comme erroné s'avère en effet basé sur un choix conscient du traducteur visant à réconcilier tous les intérêts en jeu, si divergents soient-ils.
Ce document est protégé par la loi sur le droit d'auteur. L'utilisation des services d’Érudit (y compris la reproduction) est assujettie à sa politique d'utilisation que vous pouvez consulter en ligne.

https://apropos.erudit.org/fr/usagers/politique-dutilisation/ 


\title{
Multilingual Legal Drafting, Translators' Choices and the Principle of Lesser Evil
}

\author{
KAROLINA STEFANIAK \\ European Commission, Luxembourg, Luxembourg \\ karolina.stefaniak@ec.europa.eu
}

\begin{abstract}
RÉSUMÉ
On ne parle guère de la traduction au sein des institutions de l'UE, et si l'on se penche sur le sujet, c'est pour critiquer l'énormité prétendue des coûts qu'elle entraîne, ou, pis encore, sa mauvaise qualité apparente. Il est rare que l'on tente d'appréhender les motifs réels qui conditionnent certains choix du traducteur que l'on se hâte plutôt de juger inappropriés, inattendus ou tout simplement erronés. Par le présent article, nous avons cherché à montrer comment tracer la genèse de tels choix, apparemment incongrus, dans la situation particulière de la traduction par rapport au processus de rédaction juridique dans l'UE et de la position adoptée par les traducteurs vis-à-vis des auteurs des textes traduits, dont l'enjeu, loin d'être purement intellectuel, relève davantage d'un dilemme éthique. Dans bien des cas, ce qu'un observateur externe perçoit comme erroné s'avère en effet basé sur un choix conscient du traducteur visant à réconcilier tous les intérêts en jeu, si divergents soient-ils.
\end{abstract}

\begin{abstract}
Usually the quality of EU translations is not a prominent topic in the public sphere, and when it is brought up as an issue, it is mostly criticized in the context of its allegedly high costs and the apparently low quality. The critics, however, are often unaware of the motives behind the particular translation choices, which they perceive as awkward, unusual or simply wrong. This article argues that these choices result from the particular position of translation in respect to the process of legal drafting in the EU and that of translators in respect to the draftspersons, which results not only in intellectual, but also in ethical dilemmas of the translators. It is further argued that what may be considered an error from an outsider's point of view is actually a conscious choice made by a translator trying to reconcile various divergent interests.
\end{abstract}

\section{MOTS-CLÉS/KEYWORDS}

rédaction multilingue, traduction juridique, régime linguistique, Union européenne, éthique du traducteur

multilingual drafting, legal translation, language policy, European Union, translator's ethics

\section{Introduction}

When drafting the Treaty of Paris, it was decided not to prioritize any of the languages of the founding Member States, since the imposition of one language only would certainly have spurred new conflicts, and this was exactly what the new Community was meant to prevent. Thus, a multilingual system was devised; however, until 1958, there were no specific rules in force that regulated the language regime. In 1958, Council Regulation No. 1 was adopted that provides a level playing field for the official languages of the today's European Union, with a view to enable its citizens 
an active and conscious participation in democracy and public debate by making sure they enjoy an unbridled access to the institutions as well as understand their rights and obligations ${ }^{1}$.

The Council Regulation provides for all legal acts of general application to be drafted in all official languages of the EU, whereby all the language versions are declared authentic. Similarly, the Official Journal is to be published in all official languages. Documents sent by a European institution to Member States or their citizens are to be written in the language of that Member State, whereas the public authorities and citizens of Member States can choose the language of communication with European institutions among all the official languages, and can expect to receive an answer in the same language.

Such a system guarantees the equality of the Member States, but does it also guarantee the quality of law? Divergences between language versions of the same text are rather unavoidable. However, while some see them as a problem, others point out to advantages. For example, Schilling (2010) argues that if a uniform interpretation of the diverging provisions is somehow achieved, this privileges some language versions over the others and violates the principle of their equal authenticity. On the other hand, if the authenticity of all language versions is respected and decisions in a particular case are made based on the version that concerns the given citizen, this inevitably splits the uniformity of the EU legal system. In contrast, Solan (2009) considers the existence of various language versions as an opportunity, not a hindrance, to facilitate the statutory interpretation of legal texts. The comparison of various versions of the same text is supposed to provide more evidence to the meaning of the text and the regulator's intent than monolingual legislation, without having to resort to external knowledge.

Nonetheless, these divergences are most often perceived as a result of drafting errors, and EU translators ${ }^{2}$ are the first to blame. The critics, however, rarely put importance on the fact that what they criticise are in fact legal texts, not legal translations. Moreover, they are usually unaware of the place translators have in the legal machinery of the EU and are ill-equipped to tell apart a mistake from a conscious choice. This article aims at giving some insights into the particularities of the position of EU translation in respect to legal drafting and that of EU translators in respect to the draftspersons. It is argued that EU translation is a process whereby one legal text expressed in many languages is drafted, so that translators are in fact involved in legal drafting. In spite of that they do not enjoy the same rights as the draftspersons, although they are often attributed the same responsibility. This causes internal tensions and contradictions and consequently results in intellectual and ethical dilemmas of the translators.

\section{Multilingual drafting or legal translation?}

Given the high importance of translation in the smooth functioning of the EU, one cannot help but wonder about the lack of mention of translation in the formal documents on the subject. The Council Regulation itself never uses the term "translation," but instead refers to "language versions." Neither is translation mentioned in the Interinstitutional agreement on common guidelines for the quality of drafting of Community legislation, ${ }^{3}$ nor in the Interinstitutional agreement on better law-making, ${ }^{4}$ 
nor in the Joint Practical Guide of the European Parliament, the Council and the Commission for persons involved in the drafting of legislation within the Community institutions. ${ }^{5}$

This is because the production of EU legal texts is supposed to take the form of multilingual legal drafting, and not legal translation. Multilingual drafting is usually distinguished from plain legal translation in that it is said to aim at creating one legal text (a single original) expressed in several languages, while legal translation is supposed to be performed for information purposes only, and only the version in the source language is authentic. This is not the case of the EU, where all language versions of a piece of legislation are published in the Official Journal and start applying at the same time. At this point it is not possible and not important to know which version preceded the others, since all of them are equally authentic. Šarčević is right when she claims that "from the legal point of view, it is improper to use the terms source and target texts when referring to authentic legal texts" (Šarčević 1997: 64). Joseph goes even further and suggests that the very authority of a legal text depends on the disappearance of the author and consequently that of the legal translation - on the disappearance of the translator (Joseph 1995: 18-19).

Nonetheless, the notion of multilingual drafting is still a little misleading, since drafting in the European institutions actually takes place in one language only and the preparation of the versions in the other official languages takes the form of translation. In the case of delegated acts or implementing acts translation is a separate phase between drafting and legal revision and in the case of ordinary legislative procedure there are several phases of drafting, translating and legal revision that follow each other.

In an ordinary legislative procedure, the law-making starts with a Commission proposal that is drafted in a single language, most often English, in a DirectorateGeneral competent for the subject matter. The draft proposal is then submitted for inter-service consultations to other directorates-general, the legal service and the editing service of the DGT, who may improve the linguistic and legal quality of the original text. Generally, the text should be sent to DGT for translation only after it has been finalized after inter-service consultations. However, it often happens that DGT receives the text before it is finalized, as a result of which new versions of the text, which is written and rewritten until its adoption by the College of Commissioners, are still received. New versions can also be the result of translators' comments and questions to the text sent to the requesting DG, pointing out errors and inconsistencies.

Once ready, all the translations of the Commission's proposal are sent to the Parliament and the Council, who work on the text in parallel. At this point there is no clearly identifiable master version of the text. The Council working group works on the proposal in its source language; nevertheless, Member States' experts in the working groups have the text available in their mother tongues, so that, in the end, Council amendments may be reflected in all language versions. The Council translators then receive the modifications to the Commission's proposal to translate; however, since they do not participate in the working groups' meetings, they lack the context and have no means of knowing why a particular term, phrase or wording has been chosen. They produce the language versions of the modified draft text, which is then submitted to the Committee of Permanent Representatives (COREPER) and to the Council for political agreement. 
Simultaneously, the Parliament's competent committee works on the same text. Again the committee makes the amendments to the original language version, and the amendments along with a draft report are first sent for translation into only the working languages of the committee. After the committee has voted on the amendments, the final report is translated into all official languages and sent to the plenary session in the Parliament.

In order for the text to be adopted in the first reading, the Parliament has to agree to incorporate the Council's suggestions into its own first reading amendments, and the Council has to commit itself to accept the legislative proposal as amended by the Parliament. These agreements are reached in informal meetings known as trilogues, where all the parties agree on the contents of the text, working in the source language of the proposal. In the first reading it is the Parliament who is the master of the text, which means that the text is adopted in the wording corresponding to the position of the Parliament. In practice this also means that only the substance of the Council working group's amendments is reflected in the Parliament's position, and the wording changes affecting particular language versions, agreed with Member States' experts or with Commission translators, are lost. ${ }^{6}$

The translation of the legal acts adopted by the Commission, i.e., the delegated acts and implementing acts, is simpler, but also in this case legal drafting precedes translation. Delegated acts are prepared in a single language in a similar way to legislative proposals that are adopted by the Parliament and the Council; however, all translations must be available and ready by the time of adoption by the College of Commissioners. The drafting of these acts foresees the involvement of Member States' experts in a consultative way only. As for implementing acts, they should be available in the national languages before the work in committees begins; this might often lead to a slowing down of the whole procedure of adoption, especially if urgent measures are needed. Thus, Member States' representatives in the committees often refrain from invoking this right. If they do request and receive versions in their own languages, they may introduce linguistic and terminology changes into them, although it is the Commission that will decide on the final wording of the text.

Unlike some practices in Canada or Switzerland, which apply several methods to coordinate the time and place of parallel legal drafting (e.g., Šarčević 1997: 100103), the multilingual drafting process in the EU at present, as demonstrated above, is closer to the traditional process of legal translation, although the result of this process cannot be treated as translation (Doczekalska 2009: 132). Thus, from the point of view of the product, EU does practice multilingual legal drafting, creating equally authentic language versions of a single legal text. From the point of view of the process, these language versions are produced by means of translation, with the source text existing in some form before the commencement of translation and with translators reconstructing the intent of the legislator in their respective languages on the basis of this source text.

\section{Translators' dilemmas and the principle of lesser evil}

Legal translation itself is not as special as some of its practitioners would like to see it, and it is difficult to discern characteristics that differentiate it from other types of specialized translation (Harvey 2002). There are however certain characteristics that 
make the translation of legal texts in EU institutions different from translation elsewhere. Let us start with the features of the source text. As observed before, the drafting of a legal text is a process of negotiating the substance of the text, and for practical reasons this is done in a single language, both in the Commission and in the Parliament and the Council, with translation and legal revision following later. It becomes more and more frequent though that these stages overlap. In the Commission, it is not uncommon for the translators to be working on the translation, the lawyers on the legal substance, the editing service on the quality of the source text, and the DG requesting translation on the final version of the text. This leads to numerous versions of the same text: some passages are added, others are deleted, concepts are redefined and terminology is changed. More or less substantial changes to the source text may also come at a later stage, when the translation has been finalized and sent back, and the translator introducing these changes does not have to be the same translator that originally worked on the translation.

How the instability of the source text affects translations is demonstrated by an analysis performed by Koskinen (2008). She discovered that the more the text is processed, the higher the degree of both readability and institutionalisation; this applies equally to the originals as well as to the translations. Koskinen analyzed the shifts in the subsequent versions of a Communication from the Commission, in English and Finnish. She observed that there had been a clear attempt to improve the readability and clarity of the English original; however, this attempt was neutralized by the tendency to put the institution to the forefront by the use of bureaucratic expressions or buzz words. The changes in the translation followed the same pattern: simplifying the text in some places and reproducing institutional jargon in others.

This tendency towards general rather than particular, and neutral rather than culturally marked is supposed to reduce the burden of translation by identifying and removing the sources of possible mistranslations already at the stage of source text drafting. For example, the Joint Practical Guide (see Note 5) states in point 5.2. that "the original text must be particularly simple, clear and direct, since any overcomplexity or ambiguity, however slight, could result in inaccuracies, approximations or real mistranslations in one or more of the other Community languages." Similarly, the Interinstitutional agreement on common guidelines for the quality of drafting advises the draftspersons in point 5 that "concepts or terminology specific to any one national legal system are to be used with care" to take into account the multilingual character of legal drafting. Thus "hybrid texts" (Schäffner and Adab 2001) are produced, situated at an intersection of cultures, being amalgamates of various linguistic and rhetorical features, blurring the boundaries between languages and cultures, and felt to be foreign even by the native speakers of the language of the original. Whether this actually simplifies the translator's task is doubtful. Translators are rarely aware of why particular phrases were used or why certain changes to previous versions have been made, nor do they receive feedback to their translations. With context and co-text reduced to a minimum, translators are often not able to understand where they are going and what they want to achieve. On the other hand, the amount of information of a paradigmatic character increases: specific instructions for the translation of terms, guidelines as to the wording of particular phrases, requests to translate only selected fragments or to leave them untranslated. Texts are 
deprived of their intratextual cohesion, while intertextual relations gain on importance (Pym 2011a). The use of machine translation tools during the translation process does not help diminish this lack of linearity. Forced by the architecture of the system, translators segment texts into smaller units and translate them independently from each other, on a sentence basis.

Faced with these constraints, translators' strategies to deal with such texts differ first of all depending on the type of legal act that is being translated. Regulations apply directly and have to be applied together with the national legislation, so terms originated in the national legislation are preferred. Directives, which are binding with respect to their results and have to be first implemented into the national legislation, are more general in scope by nature and usually EU terms are given priority. In this way different terminology may be used in the same domain, which creates confusion. More difficulties arise, when a sector previously regulated by a Directive begins to be regulated by a Regulation, or a Regulation implements the provisions of a Directive. In these cases translators, in the interest of legal clarity and certainty, usually stick to the terminology of the main act and give priority to the terms used previously in the Directives, although these may have been long declared deprecated and ceased to be used in newer documents.

It is, however, not the translation of technical terms that is mostly problematic, but the treatment of the EU specific vocabulary, designating new policies, instruments or bodies. Several strategies are used to render such names in the national languages. Neologisms, calques or semantic innovations are commonly used. In the case of concepts that pose particular difficulties to translators into certain languages (and what is difficult in one language is not always difficult in another), lengthy descriptions are sometimes used, optionally with the English term in brackets. Sometimes the English term is used solely. Very often, translators decide to resort to literal translation, to bring the translated term closer to the original and make it more easily recognizable as a new and specifically European concept.

Thus, some critics argue that EU translations introduce new and unnecessary words and expressions into a language that already has more suitable and wellestablished equivalents. This is, however, a misunderstanding. As David Bellos rightly notices, "both the damage translation does and the benefits it brings to the receiving language do not lie in translation itself, but in the nature of the texts that it spreads" (Bellos 2011: 194). EU law is an autonomous legal order with its own legal instruments and legal terminology, and the translation is not supposed to produce national legal acts, but EU legal acts expressed in national languages. Therefore EU specific terms cannot be translated using national terms; if an autonomous concept is used, this should be reflected in language, and translators are advised to be cautious when using language-specific terminology, or to avoid it completely. And since translators do not have an insight into the political compromises behind a particular language choice and they do not know what may yet happen with the wording of the text they translate, they prefer not to be too creative. As mentioned above, drafting and translating are separated in space and time, and translators and drafters have very little contact, if any. Unlike in multilingual drafting, they do not consult each other as to the best wording, nor do they alternate in their roles as drafters and translators. In fact, EU translators are not supposed to engage in any kind of legal drafting, they are rather expected to remain faithful to the source text, 
maintaining the surface-level similarity and striving for formal correspondence between the original and the translation (e.g., Koskinen 2008).

This restrictive understanding of fidelity is regarded as a legacy of Bible translation (e.g., Joseph 1995; Pym 2000; Harvey 2002) or of the even more ancient profession of oral translators (Bellos 2011). Nowadays, it is probably more related to the "lawyers' mistrust," the unwillingness of lawyers to grant the translators the right to interpret legal texts, although most specialists in legal translation have already redefined fidelity to refer to "the uniform intent of the single instruments, i.e., what the legislator or negotiators intended to say" (Šarčević 1997: 112). This is not to say that translators should be equalled with the authors or draftspersons in this case, since they do not have the same responsibility as the latter or, as Pym (2011b) puts it, they are not required to commit to the truth of the text they translate, which is expected from the author. Still, to require literal translation is to admit that texts have one meaning fixed by the author, over which the translator has no control. However, as Schilling reminds, "no two texts in different languages will ever have exactly the same meaning" (Schilling 2010: 50). Not even parallel legal texts. Determinacy in law is a fiction, since law cannot be separated from language, and it is virtually impossible to have a legal term that has not originated in any legal system of the EU Member States. Meaning is not hidden in the textual representation of an utterance, but is the result of interaction between the sender and the receiver, so it is quite normal that each reader, including translators, may construct a different meaning from the same text. As with any other kind of text processing, translation requires interpretation: the reception of a text by a translator is a creative act and translators cannot be expected to deliver quality work if they are relegated to the role of passive mediators.

\section{Conclusions}

If ethical behavior involves taking responsibility for one's own actions (Hewson 2007), EU translators live with the constant guilt that they can never conform to the ethics of their profession. In order to take responsibility for the texts they produce, EU translators would have to have the possibility of choice while translating. As demonstrated in the article, the conditions in which they work, including among others the quality of the source text and time available for translation, considerably limit this possibility, forcing them to make decisions based on formal fidelity and consistency rather than adequacy of meaning and uniformity of intent. Additionally, the unclear role of translators in the process of legal drafting results in conflicting demands being placed upon them. EU translators are not allowed to deviate from the original text, yet they are expected to contribute to the quality of legal drafting. They are not allowed to interpret the text they translate, yet they are blamed for the lack of clarity and readability. Is this the price of multilingualism?

\section{NOTES}

1. Translation at the European Commission - a history (2010): Luxembourg: Office for Official Publications of the European Communities.

2. Often subsumed under one headline, EU translators do not constitute a homogenous group. There are altogether eight translation services fulfilling the needs of the European Commission, the European Parliament, the Council, the Court of Justice, the Court of Auditors, the Committee of the Regions and the Economic and Social Committee in Brussels, the European Central Bank in 
Frankfurt, and the European Investment Bank in Luxembourg, and those European bodies and agencies that do not have their own translation services are served by the Translation Centre based in Luxembourg. Three of these institutions, the European Commission, the European Parliament and the Council of the European Union are directly involved in the process of law-making and so are their translation services: the Directorate General of Translation or DGT (the translation service of the European Commission constituting a separate directorate), the Directorate-General for Translation or DGTRAD (the service of the European Parliament) and the Language Services of the Council General Secretariat.

3. Interinstitutional agreement on common guidelines for the quality of drafting of Community legislation, Official Journal of the European Union C 73 of 17.3.1999, p. 1.

4. Interinstitutional agreement on better law-making, Official Journal of the European Union C 321 of 31.12.2003, p. 1.

5. The Joint Practical Guide of the European Parliament, the Council and the Commission for persons involved in the drafting of legislation within the Community institutions (2003): Luxembourg: Office for Official Publications of the European Communities.

6. For more information about the ordinary legislative procedure and the procedure of adoption in the second and third reading: Study on Lawmaking in the EU Multilingual Environment (2010): Luxembourg: Publications Office of the European Union.

\section{REFERENCES}

Bellos, David (2011): Is That a Fish in Your Ear? Translation and the Meaning of Everything. London: Penguin.

DoczeKalsKa, Agnieszka (2009): Drafting or Translation - Production of Multilingual Legal Texts. In: Frances Olsen, Alexander LoRz and Dieter Stein, eds. Translation Issues in Language and Law. Basingstoke: Palgrave MacMillan, 116-135.

Hewson, Lance (2007): Ethics and Choice. In: Christine Pagnoulle, ed. Sur le fil. Traducteurs et éthique, éthiques du traducteur. Between the devil and the deep blue sea-translators and ethics, ethics in translation. Liège: Fondation Universitaire de Belgique et du Patrimoine de l'Université de Liège, 21-30.

Harvey, Malcolm (2002): What's so special about legal translation? Meta 47(2):177-185.

Joseph, John E. (1995): Indeterminacy, Translation and the Law. In: Marshall MorRis, ed. Translation and the Law. Amsterdam/Philadelphia: John Benjamins, 13-36.

Koskinen, Kaisa (2008): Translating Institutions. An Ethnographic Study of EU Translation. Manchester: St. Jerome Publishing.

Pyм, Anthony (2000): The European Union and Its Future Languages. Questions for Language Policies and Translation Theories. Across Languages and Cultures. 1(1):1-17.

PyM, Anthony (2011a): What technology does to translating. Translation \& Interpreting 3(1):1-9.

Pyм, Anthony (2011b): The Translator as Non-Author, and I am Sorry About That. In: Claudia Buffagni, Beatrice Garzelli, Serenella Zanotti, eds. The Translator as Author. Perspectives on Literary Translation. Münster: LIT Verlag, 31-44.

ŠARČEviĆ, Susan (1997): New Approach to Legal Translation. The Hague/London/Boston: Kluwer Law International.

SChäffner, Christina and AdAB, Beverly (2001): The idea of the hybrid text in translation revisited. Across Languages and Cultures. 2(2):277-302.

Schilling, Theodor (2010): Beyond Multilingualism: On Different Approaches to the Handling of Diverging Language Versions of a Community Law. European Law Journal. 16(1):47-66.

Solan, Lawrence M. (2009): Statutory Interpretation in the EU: the Augustinian Approach. In: Frances Olsen, Alexander Lorz and Dieter Stein, eds. Translation Issues in Language and Law. Basingstoke: Palgrave MacMillan, 35-54. 